\title{
19. CHEMICAL COMPOSITION OF PACIFIC SEDIMENTS NEAR 20ㅇ: CHANGES WITH INCREASING DISTANCE FROM THE EAST PACIFIC RISE ${ }^{1}$
}

\author{
Vesna Marchig, Federal Institute of Geosciences and Natural Resources, Hannover \\ and \\ Jörg Erzinger, Mineralogisch-Petrologisches Institut, Justus-Liebig Universität ${ }^{2}$
}

\begin{abstract}
Six GEOMETEP cores sampled along a transect about $100 \mathrm{~km}$ long centered on the East Pacific Rise are compared with six DSDP Leg 92 cores sampled along a transect 350 to $1250 \mathrm{~km}$ west of the crest of East Pacific Rise. The influence of hydrothermal precipitation on the chemical character of the samples from both transects is strong and decreases with distance from the East Pacific Rise. Both the amount and the chemical composition of the hydrothermal precipitates change with distance. Near the rise, the precipitates are enriched in manganese and silica; with increasing distance from the rise the precipitates contain higher proportions of iron. The boron enrichment in the hydrothermal precipitates may outweigh the boron enrichment in marine clay minerals.

Hydrothermal production of barite and apatite at the East Pacific Rise is somewhat masked by contributions from the dissolution of calcareous tests. Hydrothermal and residual apatite can be distinguished by their yttrium contents.
\end{abstract}

\section{INTRODUCTION}

During cruise SO 26 of the GEOMETEP program (geothermal metallogenesis east Pacific) on board the German research vessel Sonne, massive sulfides were dredged in a spreading center of the East Pacific Rise (EPR) at about $20^{\circ} \mathrm{S}$ (Bäcker and Marchig, 1983; Gundlach et al., 1983; Bäcker et al., in press). Also on that cruise, a 100-km-long transect of six sediment cores was sampled on either side of the EPR at the same latitude. In this chapter, this short GEOMETEP transect is compared with the longer transect ( 350 to $1250 \mathrm{~km}$ west of the EPR) of six DSDP holes from Leg 92 (Fig. 1).

In addition to massive sulfides, the EPR in this area produces large amounts of hydrothermal oxide precipitates, which are mainly transported westward by deep water currents (Marchig et al., 1984). This combined transect gave us the opportunity to observe the changes in hydrothermal deposition with time and distance from the EPR.

\section{DESCRIPTION OF CORES}

Of the six GEOMETEP cores, the four farthest from the EPR were sampled with a 4-m-long box corer, and the two cores closer to the EPR were sampled with short piston corers. The box cores consisted of a maximum of $280 \mathrm{~cm}$ of sediment, and the piston cores consisted of from 10 to $26 \mathrm{~cm}$ of sediment. We do not know whether the collected cores represent the complete profiles down to the basaltic basement, because the box corers may have been stopped by a tephra layer.

Six sites drilled with a hydraulic piston corer during DSDP Leg 92 were investigated: Sites 600,601 , and 602

\footnotetext{
${ }^{1}$ Leinen, M., Rea, D. K., et al., Init. Repts. DSDP, 92: Washington (U.S. Govt. Printing Office).

Addresses: (Marchig) Federal Institute for Geosciences and Natural Resources, P. O. Box 5101 53, D-3000 Hannover 51, F.R.G.; (Erzinger) Mineralogisch-Petrologisches Institut, Justus-Liebig University, Senckenbergstrasse 3, D-6300 Giessen, F.R.G.
}

(630 km west of the EPR); Site $599(680 \mathrm{~km}$ west of the EPR); Site 598 ( $950 \mathrm{~km}$ west of the EPR); and Site 597 $(1250 \mathrm{~km}$ west of the EPR).

The theoretical age of the basement under the GEOMETEP cores ranges from 50,000 to 700,000 yr., a range based upon spreading rate (Rea, 1978; Rea and Scheidegger, 1979) and distance from the ridge. The age of the basement at Sites 600,601 , and 602 is estimated to be $4.6 \mathrm{~m} . \mathrm{y}$., and the age of the basement at Sites 599, 598, and 597 is estimated to be 7.8 m.y., 16 m.y., and 28.6 m.y., respectively (site chapters, this volume).

\section{METHODS OF INVESTIGATION AND RESULTS}

All samples were washed with distilled water to extract soluble salts and wet sieved through a $63 \mu \mathrm{m}$ sieve. The components of the $>63 \mu \mathrm{m}$ fractions were estimated under the microscope. The $<63 \mu \mathrm{m}$ fractions were dried and analyzed by means of X-ray fluorescence (precision of $<5 \%$ rel., calibration with standards after Abbey, 1980).

$\mathrm{CaCO}_{3}$ content determination was performed by means of selective leaching of carbonate with diluted hydrochloric acid and subsequent determination of $\mathrm{Ca}$ in the extract by EDTA titration. The precision of this method is $0.4 \%$, when tested on synthetic standards.

Sulfur content was analyzed by using LECO Sulfur Determinator SC 132 . The precision of this method is $3 \%$ when tested with LECO synthetic standards.

Boron content was determined by ICP-optical emission spectroscopy following fusion with $\mathrm{Na}_{2} \mathrm{CO}_{3}$ and dissolution with diluted $\mathrm{HClO}_{4}$, a procedure similar to that used by Owens et al. (1982). The results of the chemical analyses are compiled in Appendix Tables 1 and 2. X-ray diffraction investigations of the sediment from the adjacent area (Marchig and Gundlach, 1982) revealed a nearly totally amorphous hydrothermal phase. Therefore, no X-ray diffraction was performed on GEOMETEP material. X-ray diffraction on selected decarbonized samples of Leg 92 cores is planned.

\section{DISCUSSION OF RESULTS}

\section{Microscopic Observations of $>63 \mu \mathrm{m}$ Fraction}

\section{GEOMETEP Cores}

The $>63 \mu \mathrm{m}$ fraction of the GEOMETEP cores is composed mainly of well preserved foraminifers. Some 


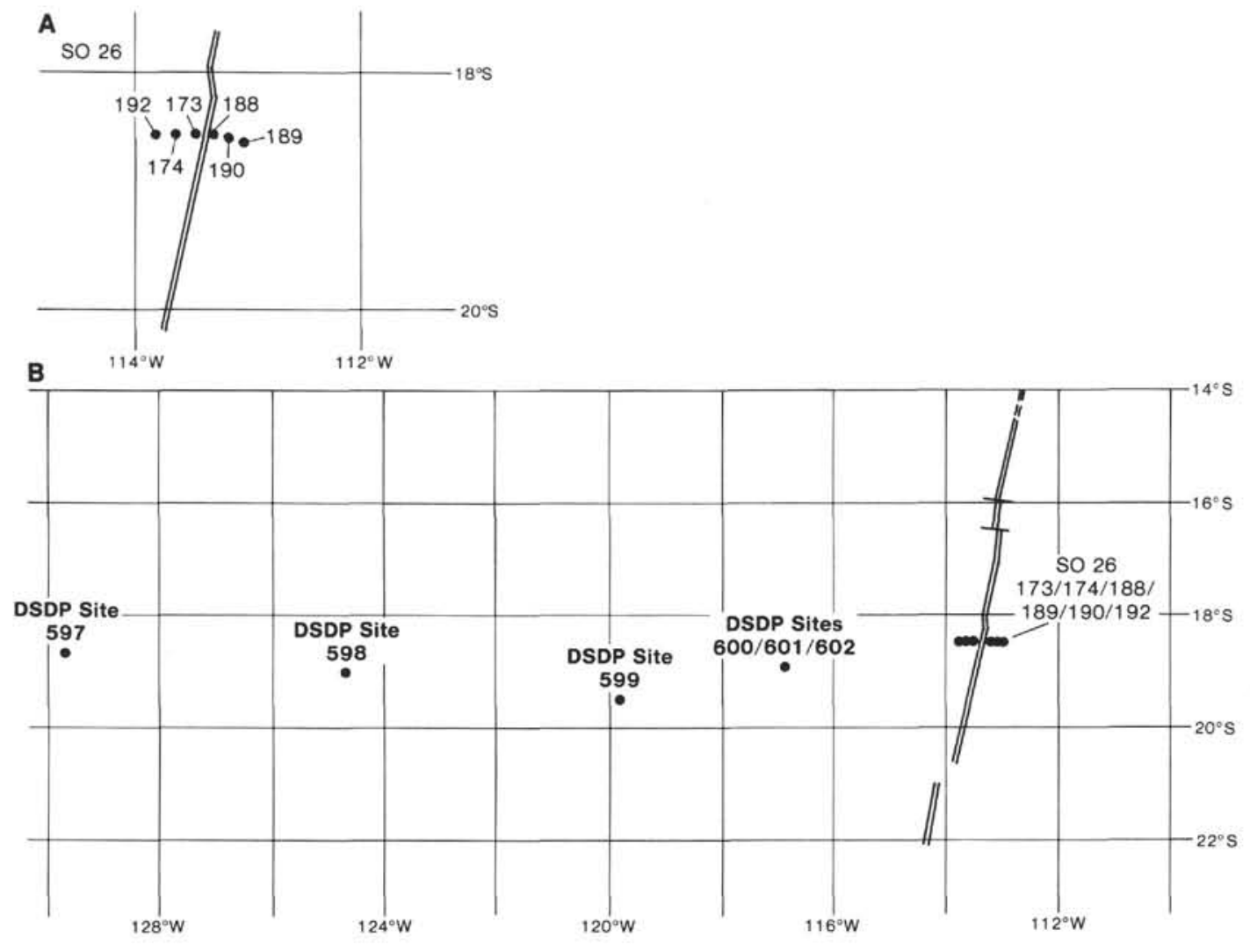

Figure 1. Sampling locations within the area of investigation. The EPR crest appears as a double line. A. SO 26 sampling locations (detail). B. SO 26 and DSDP sampling locations.

poorly sorted basalt glass fragments and sponge spicules are present in trace amounts. Zeolites, manganese micronodules, other aggregates (such as stone cores of foraminifers), and residual biogenic apatite are absent. Thus, these indicators of diagenesis (von Stackelberg, 1979) are missing in the cores. Radiolarians and diatoms are also absent.

\section{Leg 92 Cores}

Foraminifers also form most of the $>63 \mu \mathrm{m}$ fraction in the Leg 92 cores, but in contrast to the foraminifers from the GEOMETEP cores, the foraminifers of the Leg 92 cores reveal indications of diagenetic change. These indications are the filling of foraminifers with aggregates and the dissolution as well as the recrystallization of foraminiferal calcareous tests. There is no continuous trend of increasing diagenetic influence with increasing depth in the core.

Two kinds of aggregates were observed, both of them abundant in the deeper parts of the cores: one is a lightcolored larger aggregate with a rough surface, about the same in dimension as the foraminiferal tests, and the other is a smaller orange-colored aggregate with a smooth surface. The larger aggregates are thought to be diagenetic fillings of foraminiferal tests, which remain after the tests have been crushed or dissolved. The smaller aggregates are unique to this sediment type. Both types of aggregates are present in quantities too small to permit chemical or X-ray diffraction analysis, but we plan to investigate them with scanning electron microscopy and subsequent X-ray fluorescence analysis.

Biogenic apatite, mostly fragmented fish teeth, is present in trace amounts, and in some samples it is present in larger quantities. Zeolites are observed only in the top part of Hole 597, which was deposited below the carbonate compensation depth (CCD).

Manganese micronodules are present in trace amounts; they occur together with the aggregates described above and fish teeth, these objects indicating sedimentary diagenesis.

Basaltic glass fragments are occasionally present in trace amounts. Opaline tests (radiolarians and diatoms) are missing in the Leg 92 cores as well as in the GEOMETEP cores. The exceptions are very rare sponge spicules.

\section{Carbonate Content of $<63 \mu \mathrm{m}$ Fraction}

The surface sediments of the six GEOMETEP cores show an increase in carbonate content with increasing distance from the EPR (see Fig. 2). The carbonate contents in these six cores do not show signs of dissolution, so they presumably reflect the primary carbonate content. The explanation for the decrease in $\mathrm{CaCO}_{3}$ toward the EPR is dilution with hydrothermal matter. The decrease in carbonate content toward the ridge is much more pronounced on the eastern side of the EPR than on the western side. This observation can be explained by westward abyssal currents at this locality (Lonsdale, 1976). Thus, sedimentation of hydrothermal precipitates 


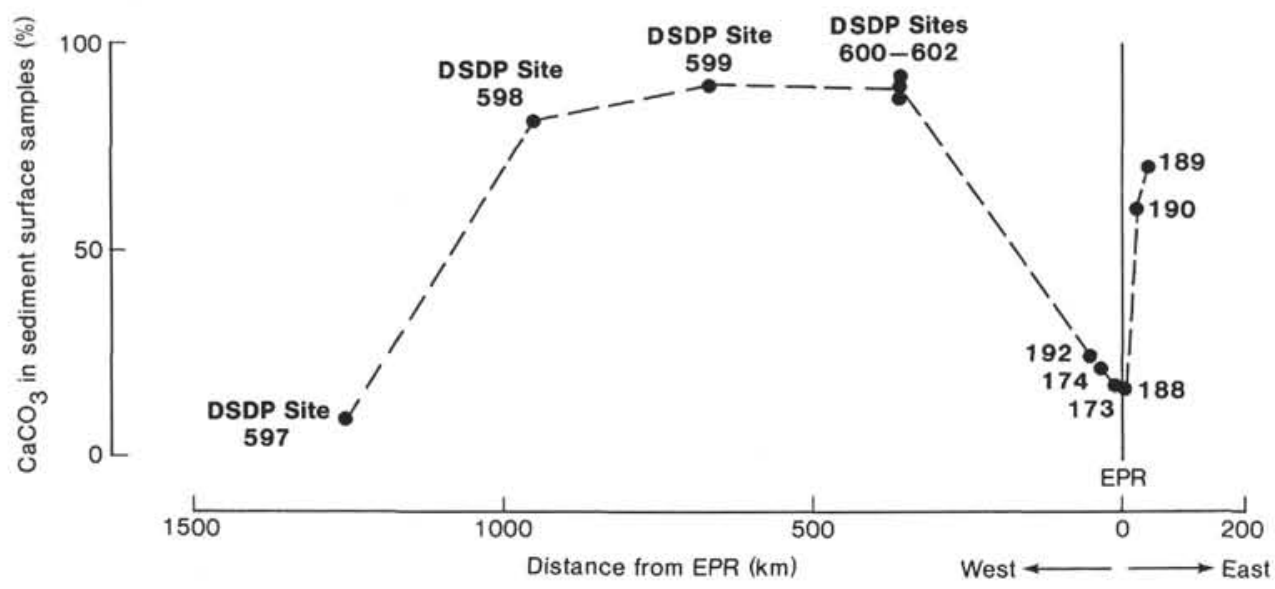

Figure 2. $\mathrm{CaCO}_{3}$ content of samples from sediment surface plotted against the distance of the sites from EPR crest.

is enhanced toward the west, and carbonate particles are diluted over larger distances (Marchig et al., 1984).

Because the very top of the sedimentary column was not sampled by the Leg 92 cores and because strong dissolution of calcite was observed in these cores, their carbonate content can hardly be compared with the carbonate content of the GEOMETEP cores. However, the increase of carbonate content to $90 \%$ in the uppermost layers of Holes 599 to 602 (Fig. 2) shows that the dilution of sedimented biogenic calcite with other material decreases as distance from the EPR increases. The uppermost layer of Hole 598 has a significantly lower carbonate content, and the uppermost layer of the most distant Hole 597, which sedimented beneath the CCD, contains only $9 \% \mathrm{CaCO}_{3}$. In these two holes, dissolution of carbonate is the principal factor influencing the carbonate content.

If the quantity of biogenic calcite in the sediment close to the EPR is controlled essentially by the dilution of carbonate by hydrothermal material, then the deeper parts of the cores should contain less carbonate, because they were formed closer to the EPR. This is the case, as a general rule, for most of the investigated cores. However, the distribution of $\mathrm{CaCO}_{3}$ in the cores is also affected by other factors, such as changes in primary carbonate production, erosion, and slumping.

\section{Carbonate-Free Material}

The carbonate-free material of the investigated cores is a typical hydrothermal sediment produced at oceanic spreading centers with abundant $\mathrm{Fe}$ and $\mathrm{Mn}$ hydroxides and very low Al contents (Boström and Peterson, 1966; Boström, 1973; Marchig and Gundlach, 1982). The hydrothermal phase of the carbonate-free material is diluted with changing amounts of silicates-volcanic glass and detrital or authigenic clay minerals. The microscopic investigation of the $>63 \mu \mathrm{m}$ fraction indicates that the diluting silicate component of the GEOMETEP cores is mainly volcanic glass; the Leg 92 cores reveal clays as well as volcanic glass as silicate components. The Mn and Fe portion in the carbonate-free material of the GEOMETEP cores is constantly high and does not show system- atic changes with increasing depth in the core. The Mn and Fe portion in the DSDP cores is somewhat lower and shows a conspicuous change with increasing depth in the core. The change in manganese content is especially strong (see Fig. 3).

To be able to explain this abrupt change in chemical composition we have to assume that the conditions of sedimentation or the properties of the sediment changed. A change in the hydrothermal production of the EPR can be excluded as a reason, because such a change in hydrothermal production would cause changes in all cores at the same sediment age. Our observations indicate that, on the contrary, the change occurred at different ages, from $24 \mathrm{Ma}$ in the most distant hole (597) through continuously younger ages, and down to $1.5 \mathrm{Ma}$ in Hole 601. An enrichment due to the diagenetic mobilization and reprecipitation of manganese can also be excluded, because the manganese-rich layer is the deepest one (it lies directly over the basement).

The mechanism we suggest as the explanation for the chemical changes in the cores is based on the movement of the plates as the result of seafloor spreading. The hydrothermal material differentiated during transport through the seawater and changed in chemical composition with increasing distance from the EPR. As a consequence, the chemical composition of the hydrothermal material that sedimented near the EPR is different from that of the material sedimented far from the EPR. In addition, water depth increases with increasing distance from the ridge and the sedimentation rate of hydrothermal material decreases. All of this can cause changes in the chemical composition of the sediments because of greater dissolution and stronger diagenetic influence. These factors could also explain the different ages of the chemical changes in the holes; because Hole 597 reached the required distance from the EPR first, the age of its sedimentation change is the oldest.

The distance from the EPR that causes the described sedimentation change must be between 50 and $360 \mathrm{~km}$ west of the EPR, because the GEOMETEP cores have not yet undergone the sedimentation change and the youngest DSDP hole already shows it. 


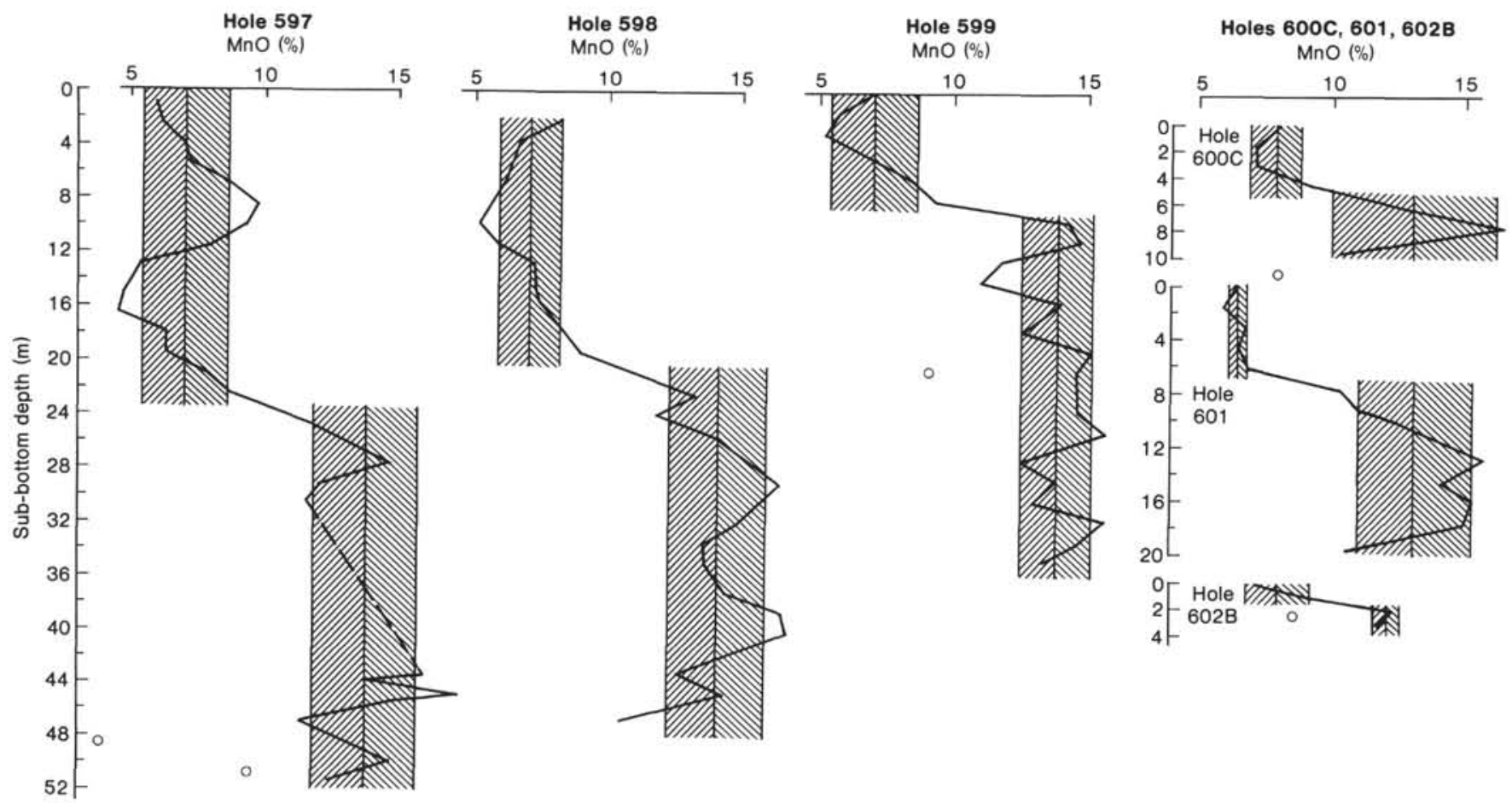

Figure 3. Changes in $\mathrm{MnO}$ content calculated on carbonate-free basis with depth in the hole. Vertical line represents the mean value, and hatched area represents standard deviation for that part of the hole. Empty circles denote samples excluded from the calculation of mean values because they are suspected of being allochthonous material or basaltic ash layers.

We used the observations described above to divide the investigated material into three groups: (1) GEOMETEP material sedimented in the vicinity of the EPR and in shallower water; (2) DSDP material, now positioned in the deeper parts of the holes, but also sedimented in shallower water in the vicinity of the EPR; (3) DSDP material from the upper parts of the holes, sedimented at distance from the EPR and in deeper water.

In Figure 4 the different types of sediment are shown in a spatial framework. First the material sedimented near the EPR covered the basaltic basement. After the plate drifted away from the EPR, the early material became covered by other material, which was sedimented farther away from the EPR. The upper layer must thin out somewhere between the GEOMETEP cores and DSDP Holes 599 to 601 .

\section{Amounts of Hydrothermal and Silicate Materials in $<63 \mu \mathrm{m}$ Fraction}

In the literature, several methods are proposed to calculate the amount of hydrothermal and silicate components in sediments from active ridges. For our investigation, we decided to use the method described by Boström (1973), because this method considers the mixing of hydrothermal material with two different silicate species, as is observed in our samples.

Figure 5 shows the top part of two modified mixing curves after Boström (1973). The lower curve is calculated from the mixture of hydrothermal sediment with tholeiitic basalt, and the upper one is calculated from the mixture of hydrothermal sediment with average continental crust (detrital silicate). From the position of the average values for the carbonate-free $<63 \mu$ m fraction

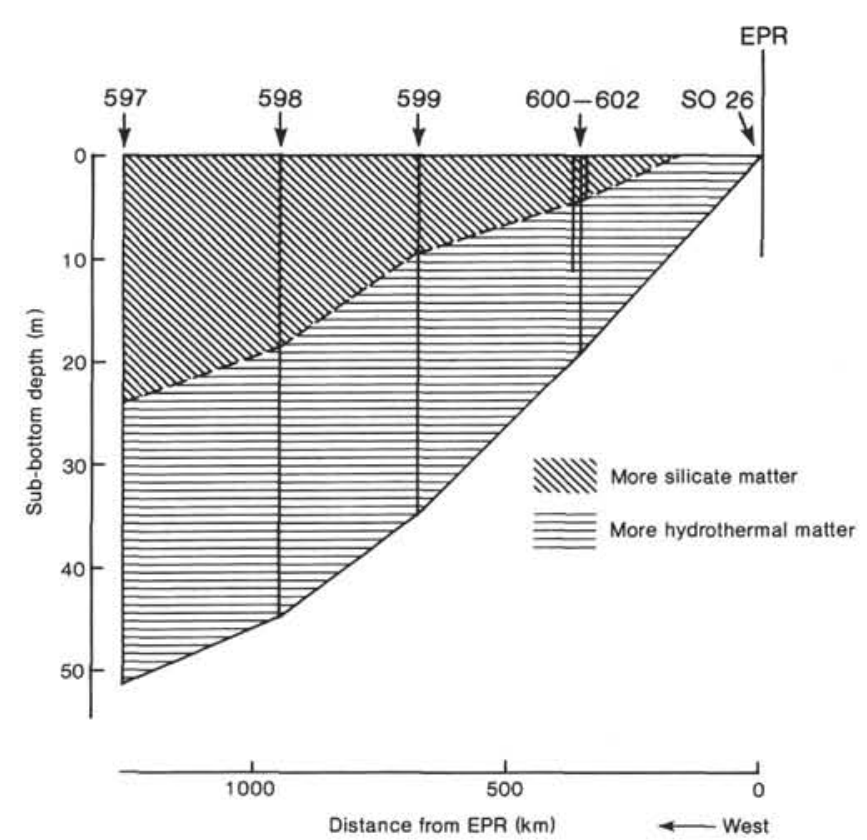

Figure 4. Assumed stratigraphic profile for the holes investigated. The underlying sediment layer (horizontal hatching) accumulated near the EPR and has more hydrothermal matter. The top sediment layer (diagonal hatching) accumulated at a distance from the EPR and has less hydrothermal matter. The latter layer thins out toward the EPR.

of the investigated sediment in these curves we can conclude that (1) GEOMETEP material is on the average a mixture of $92 \%$ hydrothermal material and $8 \%$ tholeiitic basalt; (2) the upper layer of the DSDP cores is a mix- 


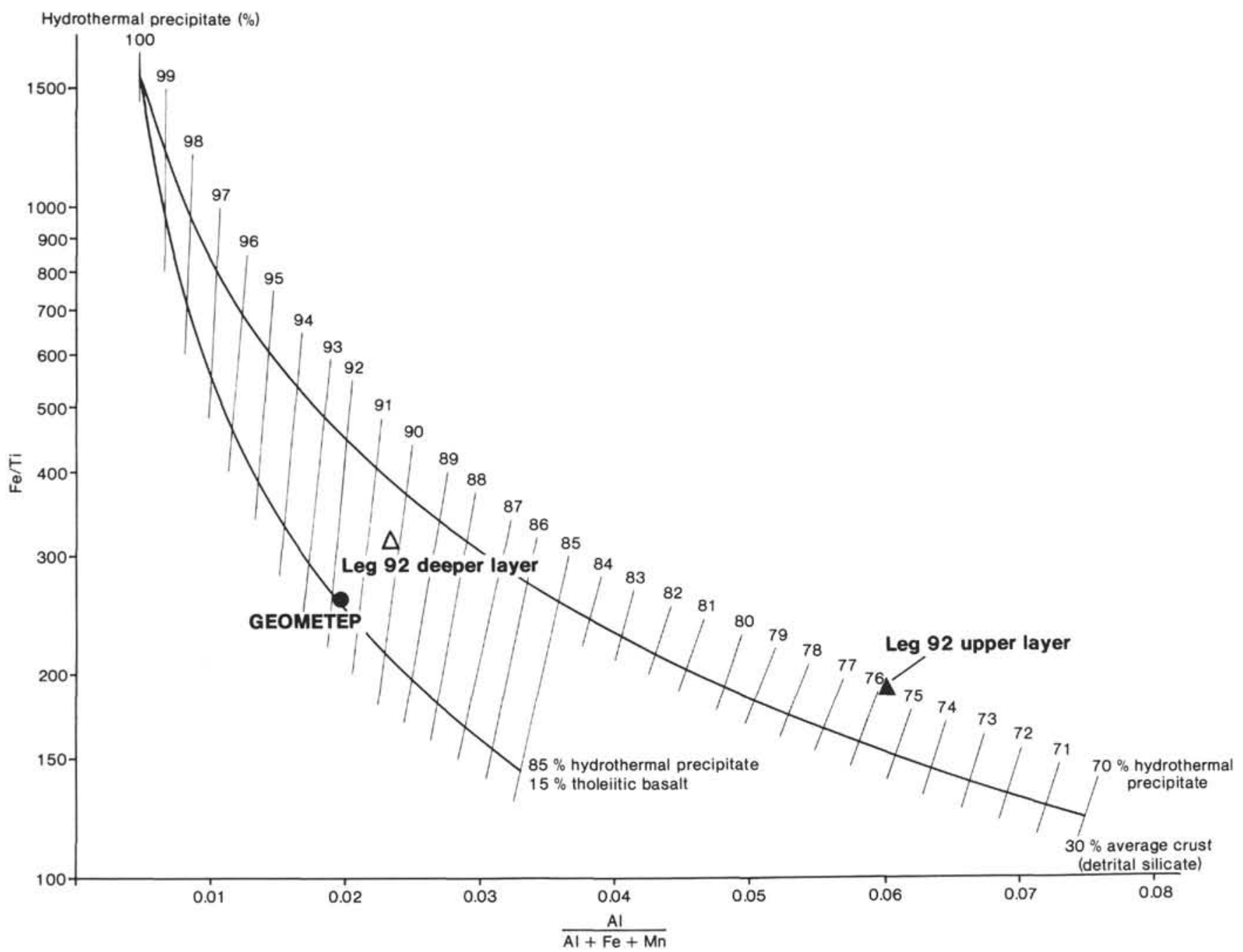

Figure 5. Mixture curves after Boström (1973) recalculated with following compositions of end members: (1) active ridge sediment-31.36\% Fe, $0.02 \% \mathrm{Ti}, 0.20 \% \mathrm{Al}$, and $11.64 \% \mathrm{Mn}$ (maximum values for $\mathrm{Fe}$ and $\mathrm{Mn}$ and minimum values for $\mathrm{Al}$ and $\mathrm{Ti}$ calculated on carbonate-free basis from GEOMETEP material); (2) average continental crust $-5.63 \% \mathrm{Fe}, 0.57 \% \mathrm{Ti}, 8.23 \% \mathrm{Al}$, and $0.095 \% \mathrm{Mn}$ (from Beus, 1976); (3) tholeiitic basalt $-8.86 \% \mathrm{Fe}, 1.17 \% \mathrm{Ti}, 7.47 \% \mathrm{Al}$, and $0.20 \% \mathrm{Mn}$ (unpubl. results; average of 71 analyses of tholeitic basalt from investigation area). The symbols represent the mean values of the three groups of sediments investigated (Leg 92 upper layer, Leg 92 deeper layer, and GEOMETEP).

ture of $76 \%$ hydrothermal material and $24 \%$ detrital silicate; and (3) the deeper layer of the DSDP cores is very similar to the GEOMETEP material. The silicate is a mixture of tholeiitic basalt and detrital clays.

Table 1 shows a comparison of average values of the different sediment layers on a carbonate-free basis. The carbonate-free matter of the deeper layer in Leg 92 cores is very similar to the carbonate-free matter precipitated near the spreading center (GEOMETEP cores). It is enriched in typical hydrothermal components like $\mathrm{Fe}, \mathrm{Mn}$, $\mathrm{Mg}, \mathrm{V}, \mathrm{Ni}$, and As (Marchig and Gundlach, 1982; Marchig et al., 1982) as well as in boron. The carbonate-free matter of the upper layer of Leg 92 cores is, in contrast, enriched in typical silicate components like $\mathrm{Al}, \mathrm{K}, \mathrm{Rb}$, and Ti. This, so far, confirms the proposed model of two layers, the deeper one richer in hydrothermal matter and the upper one lower in the content of hydrothermal matter, but still strongly influenced by hydrothermal precipitation.
Complex sedimentary and diagenetic processes that affected the discussed profiles are presumably superimposed on this simplified model. Many of these processes need further investigation. However, in the following sections we can attribute some observations to specific sedimentary and diagenetic processes.

\section{Behavior of Manganese and Iron in Hydrothermal Precipitates}

As already mentioned, there is a pronounced change in the manganese content in all the Leg 92 holes investigated (Fig. 3). The increase in manganese takes place at different depths in different holes; the depth in the hole at which the increase in manganese occurs increases with increasing distance from the EPR.

From Figure 5, it can be concluded that the deeper parts of the Leg 92 cores (the parts beneath the manganese change) contain higher amounts of hydrothermal matter. An increase in hydrothermal matter in the deeper 
Table 1. Mean values and standard deviations of the element concentrations in Leg 92 and GEOMETEP cores (calculated on carbonate-free basis).

\begin{tabular}{|c|c|c|c|c|}
\hline & $\begin{array}{l}\text { Upper part of } \\
\text { Leg } 92 \text { cores }^{\mathrm{a}} \\
(n=52)\end{array}$ & $\begin{array}{l}\text { Confidence level }(\%) \\
\text { concerning validity of } \\
\text { the difference between } \\
\text { upper and lower parts } \\
\text { of Leg } 92 \text { cores }\end{array}$ & $\begin{array}{l}\text { Lower part of } \\
\text { Leg } 92 \text { cores }^{\mathrm{a}} \\
\quad(n=64)\end{array}$ & $\begin{array}{c}\text { GEOMETEP } \\
\text { cores } \\
(n=49)\end{array}$ \\
\hline $\begin{array}{l}\text { Approximate mean } \\
\text { percentage of hydro- } \\
\text { thermal matter within } \\
\text { the carbonate-free } \\
\text { fraction }\end{array}$ & 0.75 & - & 0.90 & 0.92 \\
\hline \multicolumn{5}{|l|}{$\begin{array}{l}\text { Elements correlated to } \\
\text { hydrothermal matter }\end{array}$} \\
\hline $\mathrm{MnO}(\%)$ & $7.06 \pm 1.26$ & 99.9 & $13.45 \pm 2.12$ & $11.10 \pm 1.92$ \\
\hline $\mathrm{MgO}(\%)$ & $0.34 \pm 0.58$ & 99.9 & $1.07 \pm 0.76$ & $1.80 \pm 0.27$ \\
\hline$V(\mathrm{ppm})$ & $1045 \pm 266$ & 99.9 & $1220 \pm 186$ & $1087 \pm 154$ \\
\hline $\mathrm{Ni}(\%)$ & $0.056 \pm 0.022$ & 99 & $0.067 \pm 0.021$ & $0.047 \pm 0.015$ \\
\hline As (ppm) & $275 \pm 83$ & 95 & $304 \pm 52$ & $402 \pm 56$ \\
\hline $\mathrm{Fe}_{2} \mathrm{O}_{3}(\%)$ & $42.33 \pm 6.68$ & - & $44.12 \pm 4.03$ & $40.76 \pm 2.49$ \\
\hline $\mathrm{B}(\mathrm{ppm})^{\mathrm{b}}$ & $191 \pm 25$ & - & $186 \pm 13$ & n.d. \\
\hline \multicolumn{5}{|l|}{$\begin{array}{l}\text { Elements correlated to } \\
\text { silicate matter }\end{array}$} \\
\hline $\mathrm{P}_{2} \mathrm{O}_{5}(\%)$ & $2.73 \pm 0.87$ & - & $2.41 \pm 1.23$ & $3.73 \pm 0.96$ \\
\hline $\mathrm{TiO}_{2}(\%)$ & $0.25 \pm 0.12$ & 99 & $0.16 \pm 0.18$ & $0.18 \pm 0.15$ \\
\hline $\mathrm{K}_{2} \mathrm{O}(\%)$ & $0.30 \pm 0.31$ & 99 & $0.14 \pm 0.18$ & $0.13 \pm 0.22$ \\
\hline $\mathrm{SO}_{3}(\%)^{\mathrm{b}}$ & $0.49 \pm 0.23$ & 99.9 & $0.22 \pm 0.22$ & n.d. \\
\hline $\mathrm{Al}_{2} \mathrm{O}_{3}(\%)$ & $4.22 \pm 1.63$ & 99.9 & $1.86 \pm 1.44$ & $1.39 \pm 0.77$ \\
\hline $\mathrm{SiO}_{2}(\%)$ & $13.39 \pm 4.16$ & 99.9 & $9.89 \pm 3.39$ & $11.58 \pm 2.85$ \\
\hline $\mathrm{Y}(\mathrm{ppm})$ & $450 \pm 198$ & 99.9 & $179 \pm 82$ & $106 \pm 35$ \\
\hline $\mathrm{La}(\mathrm{ppm})$ & $443 \pm 236$ & 99.9 & $243 \pm 234$ & $88 \pm 35$ \\
\hline $\mathrm{Zr}(\mathrm{ppm})$ & $479 \pm 124$ & 99.9 & $204 \pm 101$ & $105 \pm 41$ \\
\hline $\mathrm{Rb}(\mathrm{ppm})$ & $58 \pm 24$ & 99.9 & $25 \pm 12$ & $11 \pm 11$ \\
\hline Co (ppm) & $227 \pm 117$ & 99.9 & $110 \pm 53$ & $32 \pm 25$ \\
\hline $\mathrm{Ba}(\mathrm{ppm})$ & $4911 \pm 3101$ & 99.9 & $2590 \pm 1811$ & $2374 \pm 1305$ \\
\hline $\mathrm{Cu}(\%)$ & $0.16 \pm 0.036$ & 99.9 & $0.14 \pm 0.017$ & $0.12 \pm 0.026$ \\
\hline
\end{tabular}

Notes: $n=$ number of samples; $-=$ does not apply; n.d. = not detected.

a See text for explanation of hole subdivision.

${ }^{b} \mathrm{~B}$ and $\mathrm{SO}_{3}$ values for Holes 599 and 601 only.

layer of Leg 92 cores cannot be the only reason for the increase in $\mathrm{Mn}$, however, because $\mathrm{Fe} / \mathrm{Mn}$ ratios are changing as well. Near the EPR (in the GEOMETEP cores), the sediments have an average $\mathrm{Fe}_{2} \mathrm{O}_{3} / \mathrm{MnO}_{2}$ ratio of 2.96 . The ratio of 2.68 for the deeper layer of Leg 92 cores is very similar to this. The sediment of the upper layer of Leg 92 cores shows an average $\mathrm{Fe}_{2} \mathrm{O}_{3} / \mathrm{MnO}_{2}$ ratio of 4.89 .

Figure 6 shows $\mathrm{MnO}_{2}$ plotted against $\mathrm{Fe}_{2} \mathrm{O}_{3}$ on a carbonate-free basis in all the samples analyzed, as well as mean values and standard deviations for the three groups of sediments. Again, the similarity between the GEOMETEP samples and the deeper layer of Leg 92 cores can be observed in $\mathrm{Fe} / \mathrm{Mn}$ ratio. The upper layer of the Leg 92 cores shows similar Fe values, but much lower Mn values.

The higher amount of silicates in the upper layer of the Leg 92 cores could shift the $\mathrm{Fe}_{2} \mathrm{O}_{3} / \mathrm{MnO}_{2}$ ratio of these samples to higher values, because silicates have higher $\mathrm{Fe}_{2} \mathrm{O}_{3} / \mathrm{MnO}_{2}$ ratios than hydrothermal precipitates. According to Figure 5, increasing the silicate component to the $24 \%$ value that characterizes the upper layer would increase the $\mathrm{Fe}_{2} \mathrm{O}_{3} / \mathrm{MnO}_{2}$ ratio by 0.13 . The actual increase of $\mathrm{Fe}_{2} \mathrm{O}_{3} / \mathrm{MnO}_{2}$ ratio in the Leg 92 upper layer is higher by an order of magnitude, so the dilution of hy- drothermal precipitate with silicate material cannot explain the observed increase in $\mathrm{Fe}_{2} \mathrm{O}_{3} / \mathrm{MnO}_{2}$ ratio.

The theory proposed in the section on carbonate-free material suggests that the differences between the upper and deeper layers of the Leg 92 cores are due to seafloor spreading, that is, changing distance from the EPR, and the previous results could be interpreted as the result of the differentiation of hydrothermal precipitates during transport through seawater. The iron content in hydrothermal precipitates does not change significantly with transport through the seawater, but manganese precipitates in higher quantities near the ridge, so that the Mn/ $\mathrm{Fe}$ ratio would decrease with increasing distance from the EPR.

\section{Distribution of $\mathrm{SiO}_{2}$ in Aluminosilicates and Hydrothermal Precipitates}

Previous investigations of hydrothermal precipitates (Marchig and Gundlach, 1982) show that as much as $10 \%$ of the $\mathrm{SiO}_{2}$ is contained in hydrothermal precipitates, and probably coprecipitates from hydrothermal solution together with iron and manganese hydroxides. The content of aluminosilicates in pure hydrothermal precipitates is lower than 1\% (Marchig and Gundlach, 1982); 


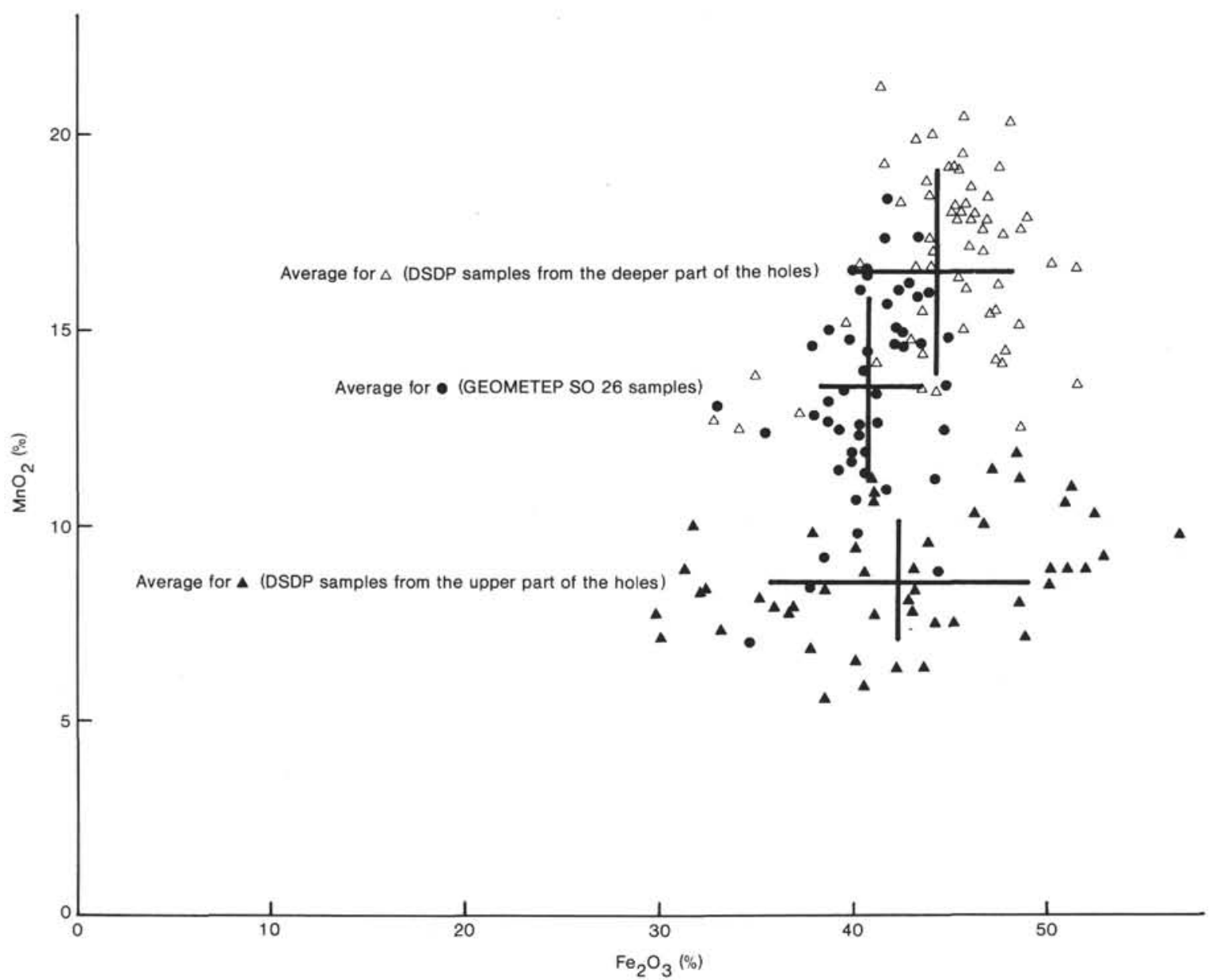

Figure 6. $\mathrm{MnO}_{2}$ plotted against $\mathrm{Fe}_{2} \mathrm{O}_{3}$ for the carbonate-free matter of fractions $<63 \mu \mathrm{m}$. Average values and standard deviations for the three groups of sediments appear as crosses.

that is, most of the aluminosilicates found in hydrothermally influenced sediments around the EPR are not of hydrothermal origin. They are composed of volcanic glass, detrital clay minerals, and diagenetic clay minerals.

In order to discriminate between $\mathrm{SiO}_{2}$ from aluminosilicates and $\mathrm{SiO}_{2}$ bound to hydrothermal precipitates, $\mathrm{Al}_{2} \mathrm{O}_{3}$ was plotted against $\mathrm{SiO}_{2}$ (Fig. 7). If it is assumed that all the $\mathrm{Al}_{2} \mathrm{O}_{3}$ is bound to aluminosilicates, the intersections of the linear regression lines with the $\mathrm{SiO}_{2}$ axis show the amounts of $\mathrm{SiO}_{2}$ bound to hydrothermal precipitates. Figure 7 demonstrates that there are two different linear correlations, one for the GEOMETEP material and the other one for the upper layer of Leg 92 cores. The hydrothermal precipitates of the GEOMETEP sediments contain significantly more $\mathrm{SiO}_{2}$ than the hydrothermal precipitates from the upper layer of the Leg 92 cores.

In the section on carbonate-free material we proposed seafloor spreading as the reason for the differences in the chemical composition of the sediments. By using this theory we can also explain the differences in the $\mathrm{SiO}_{2}$ content of the hydrothermal precipitates: first, the $\mathrm{SiO}_{2}$ richer precipitate sediments near the EPR, while the rest, precipitating later and becoming depleted in $\mathrm{SiO}_{2}$, is transported farther away from the EPR. As a consequence, the upper parts of the Leg 92 cores, which sedimented at a distance from the EPR, contain less $\mathrm{SiO}_{2}$ in the hydrothermal portion. The GEOMETEP material, which sedimented recently near the EPR, is enriched in that part of $\mathrm{SiO}_{2}$ which is bound to the hydrothermal phase. The deeper part of Leg 92 cores should, according to the proposed model, also have been precipitated in the vicinity of the EPR. In Figure 7 this sediment occupies a position between the GEOMETEP material and the upper layer of the Leg 92 cores. It is possible that the deeper layer has been affected somewhat by diagenesis, since it is older than the GEOMETEP material. Further investigation, including X-ray diffractometry, could explain the observed difference.

Behavior of Phosphorus in Hydrothermal Precipitates and Discrimination of Hydrothermal and Biogenic Phosphorus

The carbonate-free portion of the Leg 92 samples contains, on the average, 2.5\% $\mathrm{P}_{2} \mathrm{O}_{5}$ (see Table 1). Microscopic observations of the $>63 \mu \mathrm{m}$ fraction of these cores reveal widespread fragments of fish teeth. Inasmuch as the dissolution of calcite was also observed in this sediment (see the section called Leg 92 Cores), the widespread fish debris has consequently enriched the sedi- 




Figure 7. $\mathrm{Al}_{2} \mathrm{O}_{3}$ plotted against $\mathrm{SiO}_{2}$, both on carbonate-free basis. Linear correlations are drawn for two groups of sediments: upper part of Leg 92 cores and GEOMETEP cores.

ment with a residual biogenic component (Cronan, 1980). The apatitic fish debris accounts for a considerable part of the $\mathrm{P}_{2} \mathrm{O}_{5}$ content of the Leg 92 sediments.

The average $\mathrm{P}_{2} \mathrm{O}_{5}$ content of the GEOMETEP samples is $3.7 \%$. This phosphorus content cannot be attributed to biogenic apatite, because no apatitic debris was observed in the $>63 \mu \mathrm{m}$ fraction of these sediments. Therefore most of the phosphorus in these sediments must be of hydrothermal origin. The precipitation of phosphorus from hydrothermal solution (also in the form of apatite; see Marchig and Gundlach, 1982) takes place very soon after the hydrothermal solution is mixed with seawater; therefore, only a narrow belt several tens of kilometers wide along the spreading center accumulates significant quantities of hydrothermal apatite.

Marchig et al. (1982) proposed using the trace element content of apatite to distinguish between hydrothermal and organogenic apatite. The method is based on the observation that the levels of Sc, Y, La, and REE are higher in marine biogenic apatite than in other apatites. Figure 8 shows $\mathrm{Y}$ plotted against $\mathrm{P}_{2} \mathrm{O}_{5}$ for the three groups of sediments investigated. In the upper layers of the Leg 92 cores there is a positive correlation between $\mathrm{Y}$ and $\mathrm{P}_{2} \mathrm{O}_{5}$, and the $\mathrm{Y} / \mathrm{P}_{2} \mathrm{O}_{5}$ ratios are high, characteristics indicative of biogenic marine apatite. The GEOMETEP material has very low $\mathrm{Y}$ contents, and $\mathrm{Y}$ does not show a positive correlation with $\mathrm{P}_{2} \mathrm{O}_{5}$, evidence that the apatite near the hydrothermal source of the EPR is not of biogenic origin.
The apatite in the deeper layers of the Leg 92 cores has $\mathrm{Y}$ and $\mathrm{P}_{2} \mathrm{O}_{5}$ values that fall between those of the apatites precipitated near the hydrothermal source and those precipitated far away from the hydrothermal source. This relation suggests that the apatite is partly of hydrother$\mathrm{mal}$ and partly of biogenic origin.

The relationships between $\mathrm{La}$ and $\mathrm{P}_{2} \mathrm{O}_{5}$ follow similar trends.

\section{Sulfur and Boron}

Initial analyses of sulfur and boron in sediments from Hole 599 and Hole 601 lead to several preliminary conclusions.

Sulfur content is positively correlated with barium content (Fig. 9). In the plot of $\mathrm{Ba}$ against $\mathrm{SO}_{3}$ (Fig. 9), the composition of pure $\mathrm{BaSO}_{4}$ is also drawn as a theoreti$\mathrm{cal}$ barite line. From Figure 9 it can be concluded that there is, on the average, enough $\mathrm{SO}_{4}{ }^{2-}$ in the sediment for all the $\mathrm{Ba}$ to be bound as barite.

The upper sections of the DSDP holes have significantly higher $\mathrm{Ba}$ and $\mathrm{SO}_{3}$ contents (on a carbonate-free basis) than the deeper sections of the same holes. Barite is formed as a precipitate from hydrothermal solutions. It is also residually enriched during the dissolution of organogenic calcite (Cronan, 1980; Arrhenius and Bonatti, 1965). The enrichment of barite in the upper parts of the holes in combination with a decrease in the content of hydrothermal matter (see the section called Amounts of Hydrothermal and Silicate Materials in $<63 \mu \mathrm{m}$ Frac- 




Figure 8. Y plotted against $\mathrm{P}_{2} \mathrm{O}_{5}$, both on carbonate-free basis. Linear correlations are drawn for two groups of sediments: upper part of Leg 92 cores and GEOMETEP cores.

tion) and lower sedimentation rates is an indication that the barite in the investigated sediment is biogenically enriched.

There is little recent literature on the geochemical behavior of boron in marine sediments (see Harder, 1974, for a review of boron chemistry). Most authors have pointed out that boron is bound in clay minerals, mainly illite and montmorillonite, and that it is sometimes correlated with the $\mathrm{Mg}$ contents of the respective minerals. The boron values found in this study fall in the same range of concentrations as those reported elsewhere in the literature (Harder, 1974). These data show no correlations with $\mathrm{Al}, \mathrm{Mg}$, or $\mathrm{Si}$, but they do show a weak positive correlation with $\mathrm{Fe}_{2} \mathrm{O}_{3}$ content (Fig. 10). We suppose, therefore, that boron was brought into the sediment by means of coprecipitation with iron hydroxide. The primary source of boron could be ocean water, with its constant $4.5 \mathrm{ppm} \mathrm{B}$, or hydrothermal solution carrying boron leached from tholeiitic basalt (although tholeiitic basalts usually contain less than $0.1 \mathrm{ppm}$ B). Further analyses of B are planned and may confirm the as yet statistically weak link between boron and the hydrothermal phase.

\section{CONCLUSIONS}

The East Pacific Rise in the investigated area at latitude $20^{\circ} \mathrm{S}$ produces large amounts of oxidic hydrothermal precipitates in addition to massive sulfides. From the dilution with biogenic carbonate it can be seen that the hydrothermal material accumulates at high sedimentation rates near the EPR, with the sedimentation rates decreasing with distance from the EPR.

In Leg 92 holes two layers could be distinguished. The layers differ in their chemical composition; the upper layer contains $76 \%$ hydrothermal matter on a carbonate-free basis, and the lower layer contains $90 \%$ hydrothermal matter, which is very similar to the composition of the sediment precipitated in the vicinity of the EPR (GEOMETEP cores).

We offer the following model of sedimentation, which is corroborated by these observations and which, at the current state of investigation, best explains the observed chemical differences:

The deeper layer of the Leg 92 holes sedimented in the vicinity of the EPR and was transported away from the spreading center by means of seafloor spreading. This 


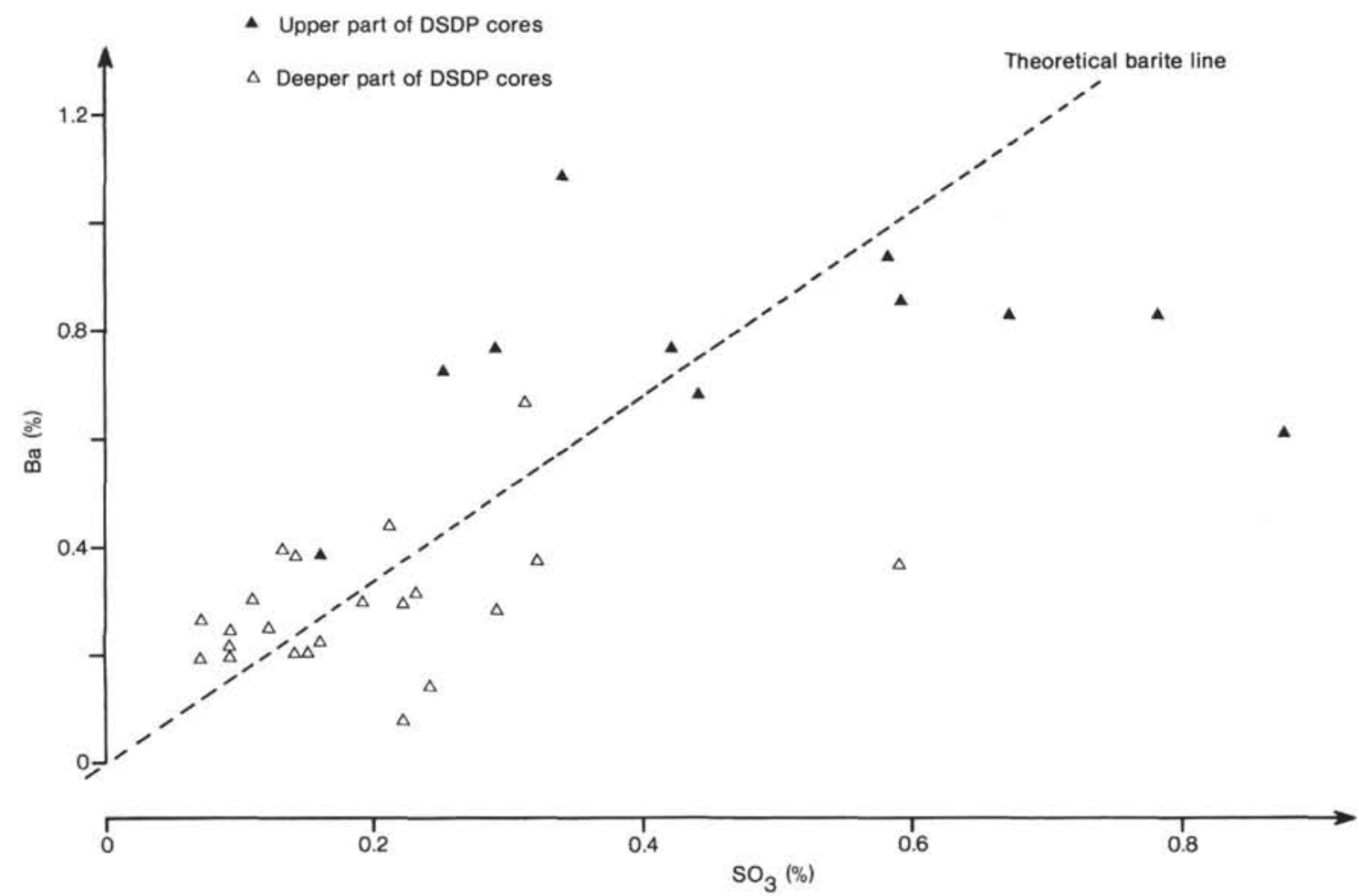

Figure 9. Ba plotted against $\mathrm{SO}_{3}$, both on carbonate-free basis, for Holes 599 and 601 from Leg 92. Dashed line is based on contents of $\mathrm{Ba}$ and $\mathrm{SO}_{3}$ in pure $\mathrm{BaSO}_{4}$.

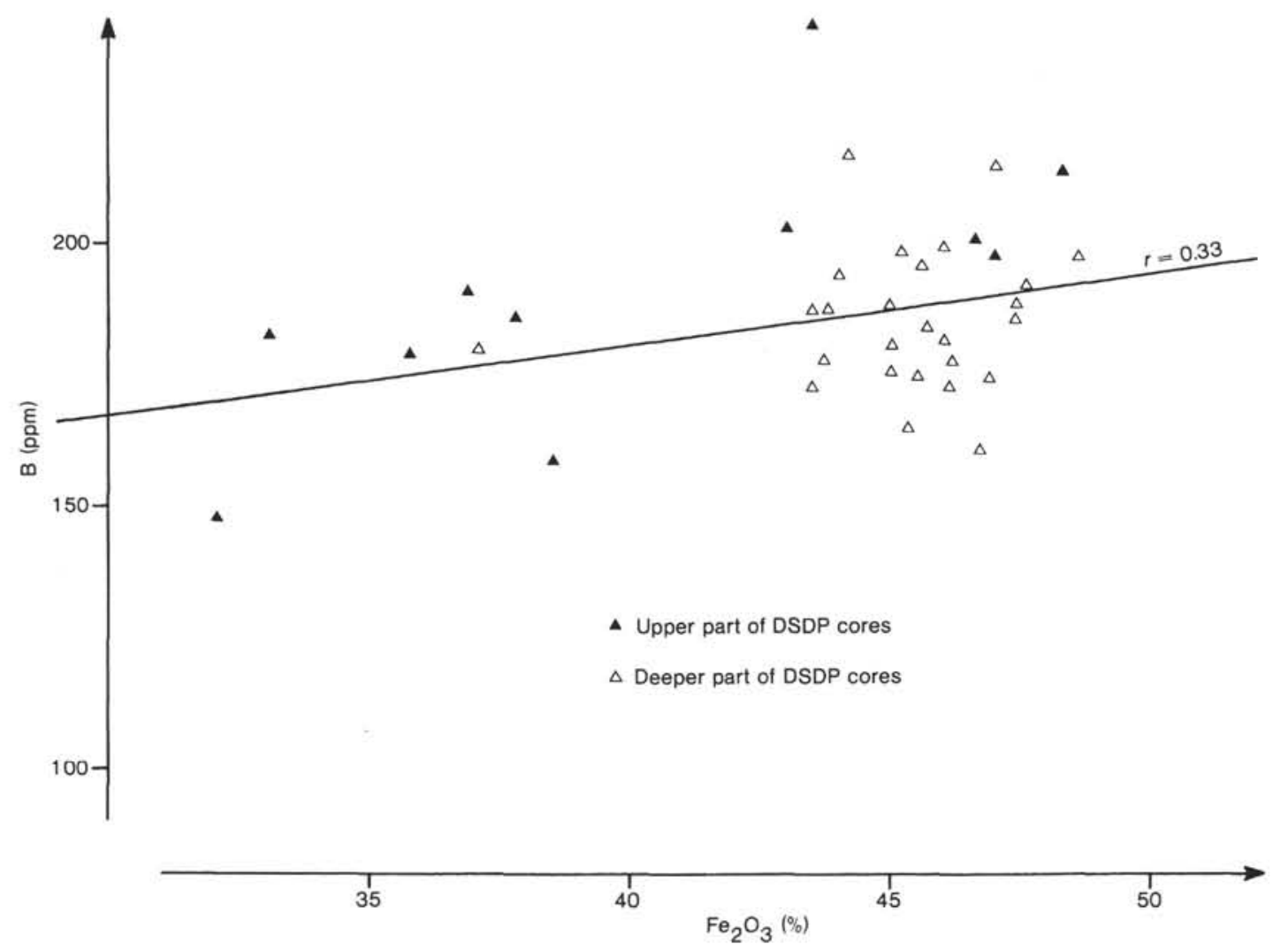

Figure 10. B plotted against $\mathrm{Fe}_{2} \mathrm{O}_{3}$ for the carbonate-free matter of Holes 599 and 601 from Leg 92 . The linear correlation is valid for all the samples analyzed. 
is the reason for its similarity with sediment that has recently accumulated in the vicinity of the EPR. The differences (such as the higher content of $\mathrm{Y}$ in apatite and different $\mathrm{Al} / \mathrm{Si}$ ratios) are due to diagenetic changes, because the deeper layer of the Leg 92 holes is the older counterpart of recently sedimented GEOMETEP cores.

As the crust moved away from the EPR, the deeper layer of the Leg 92 holes was covered with material sedimenting at greater distance from the EPR. This upper sediment layer is characterized by hydrothermal matter that is more diluted with carbonate and detrital silicate. Besides that, this layer also reveals further advanced diagenesis, as it accumulated in deeper water with lower sedimentation rates. The diagenetic changes are manifested in the form of the enrichment of residual biogenic apatite and barite after the partial dissolution of biogenic calcite.

The hydrothermal matter changes in composition during transport by seawater. The precipitates near the EPR are enriched in manganese and silica, while farther away the hydrothermal precipitate is depleted in $\mathrm{Mn}$ and $\mathrm{Si}$.

The larger portion of boron seems to reach the sediment carried by hydrothermal iron hydroxide. The larger portion of barite is of biogenic origin; barite is enriched as a residual component as the result of the partial dissolution of biogenic calcite. Apatite occurs in sediment from both sources in similar quantities; its origin can be distinguished by means of yttrium content.

\section{REFERENCES}

Abbey, S., 1980. Studies in "standard samples" for use in the general analysis of silicate rocks and minerals. Geostandards Newsl., 4(2): 163-190.

Arrhenius, G., and Bonatti, E., 1965. Neptunism and volcanism in the ocean. In Sears, M. (Ed.), Progress in Oceanography, 3:7-22.

Bäcker, H., Lange, J., and Marchig, V., in press. Hydrothermal activity and sulphide formation in axial valleys of the East Pacific Rise crest between 18 and $22^{\circ} \mathrm{S}$. Earth Planet. Sci. Lett.

Bäcker, H., and Marchig, V., 1983. Sulfide ores from the deep-sea: the research programme GEOMETEP with R/V Sonne. Meerestech$n i k, 14(4): 134-140$.
Beus, A. A., 1976. Geochemistry of the lithosphere: Moscow (Mir Publ.).

Boström, K., 1973. The origin and fate of ferromanganoan active ridge sediments. Stockholm Contrib. Geol., 27(2):1-243.

Boström, K., and Peterson, M. N. A., 1966. Precipitates from hydrothermal exhalation on the East Pacific Rise. Econ. Geol., 61:12581265.

Cronan, D. S., 1980. Underwater Minerals: London (Academic Press).

Gundlach, H., Marchig, V., and Bäcker, H., 1983. Neue Erzfunde im Pazifik. "GEOMETEP 3"-Dritte deutsche Forschungsfahrt zu aktiven Plattenrändern im Pazifik. Erzmetall, 36(10):495-500.

Harder, H., 1974. Boron. In Wedepohl, K.-H. (Ed.), Handbook of Geochemistry: (Springer Verlag) Berlin.

Lonsdale, P., 1976. Abyssal circulation of the southeastern Pacific and some geological implications. J. Geophys. Res., 81(6):1163-1176.

Marchig, V., and Gundlach, H., 1982. Iron-rich metalliferous sediment on the East Pacific Rise-prototype of undifferentiated metalliferous sediments on divergent plate boundaries. Earth Planet. Sci. Lett., 50:361-382.

Marchig, V., Gundlach, H., and Bäcker, H., 1984. Geochemical indication in deep-sea sediments for hydrothermal discharge. Mar. Geol., 56:319-323.

Marchig, V., Gundlach, H., Möller, P., and Schley, F., 1982. Some geochemical indicators for discrimination between diagenetic and hydrothermal metalliferous sediments. Mar. Geol., 50:241-256.

Owens, J. W., Gladney, E. S., and Knab, D., 1982. Determination of boron in geological materials by inductively-coupled plasma emission spectrometry. Anal. Chim. Acta, 135:169-172.

Rea, D. K., 1978. Asymmetric sea-floor spreading and nontransform axis offset: the East Pacific Rise $20^{\circ} \mathrm{S}$ survey area. Geol. Soc. Am. Bull., 89:836-844.

Rea, D. K., and Scheidegger, K. F., 1979. Eastern Pacific spreading rate fluctuation and its relation to Pacific area volcanic episodes. Volcanol. Geotherm. Res., 5:135-148.

von Stackelberg, U., 1979. Sedimentation, hiatuses, and development of manganese nodules: Valdivia site VA-13/2, northern central Pacific. In Bischoff, J. L., and Piper, D. Z. (Eds.), Marine Geology and Oceanography of the Pacific Manganese Nodule Province: New York (Plenum Press), 559-586.

Date of Initial Receipt: 25 July 1984

Date of Acceptance: 31 December 1984

\section{APPENDIX}

Chemistry of Leg 92 and GEOMETEP Sediments

The data appear as a foldout in the back pocket of this volume. 